Ethos: Jurnal Penelitian dan Pengabdian Masyarakat, Vol 8, No.2, Juni 2020: 199-204

\title{
Pelatihan Aplikasi Pembelajaran Quizizz di Sekolah Dasar Kota Bandung ${ }^{1}$ Nurul Fazriyah, ${ }^{2}$ Cartono, ${ }^{3}$ Rolly Maulana Awangga
}

\author{
1 Pendidikan Guru Sekolah Dasar, Universitas Pasundan, Bandung, ${ }^{2}$ Pendidikan Biologi, Universitas \\ Pasundan, Bandung, ${ }^{3}$ Teknik Informatika, Politeknik Pos Indonesia, Bandung \\ email: ${ }^{1}$ Nurulfazriyah@unpas.ac.id, ${ }^{2}$ Cartono@unpas.ac.id, ${ }^{3}$ Awangga@poltekpos.ac.id
}

\begin{abstract}
The role of the teacher in an effort to improve the quality of learning is very essential, this is in line with the changing demands of the changing times, the teacher should also follow the existing demands. Technology in learning is currently experiencing rapid development. The teacher also begins to modify learning by involving technology in learning. Bandung is a city that is very dynamic to change. Welcoming the Bandung Smart City launched by the city government of Bandung, the government institutions one of which is a state school to adjust it. Even though it has extraordinary potential, it needs support to maximize the potential of innovative learning that can be done. One of the improvements in pedagogical competence is the use of instructional media, the use of current media that can be utilized by students through learning applications found in students' devices. Through training learning applications Quizizz for teachers can improve digital literacy for students who really need to be developed at this time. The method of implementation was through training and mentoring of 25 elementary school teachers at SDN 164 Karangpawulang, Bandung. Based on the assistance that has been done, the results obtained in the form of a 75\% increase in knowledge of the trainees. This learning application training is very useful for teachers who have an impact on students in the class.
\end{abstract}

Keywords: quizizz, mobile learning, digital literacy

\begin{abstract}
Abstrak. Peran guru dalam usaha peningkatan kualitas pembelajaran sangat esensial, hal ini seiring sejalan dengan perubahan tuntutan jaman yang terus berkembang maka guru juga hendaknya mengikuti tuntutan yang ada. Teknologi dalam pembelajaran saat ini mengalami perkembangan pesat. Guru juga mulai memodifikasi pembelajaran dengan melibatkan teknologi dalam pembelajaran. Kota Bandung merupakan kota yang sangat dinamis terhadap perubahan. Menyongsong Bandung Smart City yang dicanangkan oleh pemerintah Kota Bandung, maka institusi pemerintah salah satunya adalah sekolah negeri menyesuaikan hal tersebut. Walaupun memiliki potensi yang luar biasa maka perlu sokongan untuk memaksimalkan potensi inovasi pembelajaran yang bisa dilakukan. Peningkatan kompetensi pedagogik salah satunya adalah penggunaan media pembelajaran, penggunaan media saat ini yang dapat dimanfaatkan siswa melalui aplikasi pembelajaran yang terdapat pada gawai yang dimiliki siswa. Melalui pelatihan aplikasi pembelajaran Quizizz bagi guru dapat meningkatkan literasi digital bagi siswa yang sangat perlu dikembangkan saat ini. Metode pelaksanaan melalui pelatihan dan pendampingan 25 guru SD yang dilakukan di SDN 164 Karangpawulang Kota Bandung. Berdasarkan pendampingan yang telah dilakukan, diperoleh hasil berupa peningkatan pengetahuan $75 \%$ dari peserta pelatihan. Pelatihan aplikasi pembelajaran ini sangat bermanfaat dilakukan bagi guru yang berdampak kepada siswa di kelas.
\end{abstract}

Kata Kunci: quiziz, mobile learning, digital literasi 


\section{Pendahuluan}

Pembelajaran masa kini terus mengalami inovasi, sesuai dengan dinamisnya tuntutan kompetensi abad 21. Perubahan paradigma cara belajar siswa yang berbeda dibandingkan masa sebelumnya. Banyak pekerjaan rumah yang harus diselesaikan guru di sekolah dengan perubahan kurikulum dan cara belajar siswa.

Literasi digital yang dikembangkan pada masa ini sangat dibutuhkan oleh anak didik. Alasannya adalah percepatan arus informasi yang tinggi sehingga siswa diminta agar bisa memfilter informasi yang begitu banyaknya. Ada pengaruh terhadap psikologi yaitu kecanduan gawai (Maovangi Day, Vania; Qodariah, 2019). Maka perlu urgensi literasi digital bagi siswa masa kini sangat penting.

Kota Bandung memiliki visi sebagai smart city, yang berimbas pada digitalisasi berbagai aspek salah satunya adalah pendidikan. Sekolah negeri merupakan representasi dari pemerintah daerah perlu juga ikut menyukseskan visi pemerintah kotanya.

Pada wilayah kota Bandung terdapat banyak sekali jumlahnya sekolah negeri tingkat dasar atau SD mencapai 200 lebih (Pusat Data Dan Teknologi Informasi Kementerian Pendidikan dan Kebudayaan, 2020). SD tersebut tersebar di berbagai lokasi dengan karakteristik masing-masing. Sekolah dasar negeri hanya memiliki dana yang tidak besar untuk mengejar ketertinggalan dengan sekolah yang mumpuni fasilitas. Berdasarkan hal tersebut, perlunya pembinaan di sekolah dasar negeri yang perlu dimaksimalkan potensinya.

Berdasarkan hasil observasi di lapangan diperoleh data sekolah negeri dengan potensi yang bagus tetapi perlu pembinaan dalam hal literasi digital.
Sekolah Negeri 164 Karang Pawulang merupakan sekolah yang terletak di Kecamatan Lengkong Kota Bandung dengan jumlah siswa yang mencapai 1000 siswa. Siswa di sekolah tersebut diperbolehkan menggunakan gawai dalam pembelajaran, hal ini dikarenakan kemampuan finansial orang tuanya yang cukup baik. Setelah dilakukan observasi dan wawancara ternyata gawai yang ada di kelas sebatas untuk menonton Youtube dan Googling saja. Belum digunakan sebagai media interaktif dalam pembelajaran. Padahal gawai yang ada sangat bermanfaat banyak jika kegunaannya dimaksimalkan oleh pendidik yaitu guru kelas. Salah satu penelitian yang dapat dijadikan contoh adalah penelitian Wahyuni, Widiyatun dkk. (Wahyuni, Widiyatun, Widyasari, \& Suharmanto, 2019:182) yang mendapatkan data bahwa siswa dapat lebih semangat jika belajar melibatkan teknologi.

Penguasaan teknologi informasi pembelajaran oleh siswa mampu merangsang munculnya generasi melek teknologi. Hal ini esensial bagi suatu negara menurut Ngafifi (Kadi \& Awwaliyah, 2017:149) negara yang maju jika menguasai teknologi informasi. Maka penguasaan teknologi informasi sehingga siswa dapat memfilter informasi yang diperolehnya (National Education Association, 2014). Selain itu, proses pembelajaran yang ada di kelas dapat menjadi lebih baik dan lebih efektif bagi guru (Wati \& Set, 2018: 227)

Permasalahan di sekolah mitra adalah para guru kelas belum menguasai aplikasi pembelajaran yang dapat digunakan di kelas saat proses belajar. Sehingga menjadi alasan utama dilakukan pengabdian di sekolah tersebut.

Aplikasi pembelajaran yang sangat bermanfaat bagi guru adalah salah satunya yaitu Quizizz. Aplikasi 
Quizizz merupakan aplikasi pembelajaran yang sangat digemari saat ini, karena sangat mudah dalam pembuatan konten, dapat membuat soal, pekerjaan rumah, tes dan kuis dengan tampilan yang menarik bagi siswa sekolah dasar.

\section{Metode}

Kegiatan pelatihan pada tanggal 9 Agustus 2019 di SDN 164 Karangpawulang. Metode pelatihan ini dengan pengarahan, diskusi dan tanyajawab, praktik langsung di lapangan dan pendampingan. Target peserta workshop yang terdiri dari guru kelas IV, V dan VI di SDN 164 Karangpawulang tercapai yaitu 25 peserta. Pemateri pelatihan aplikasi pembelajaran oleh Nurul Fazriyah, M.Pd. yang memiliki kepakaran pada bidang media pembelajaran SD.

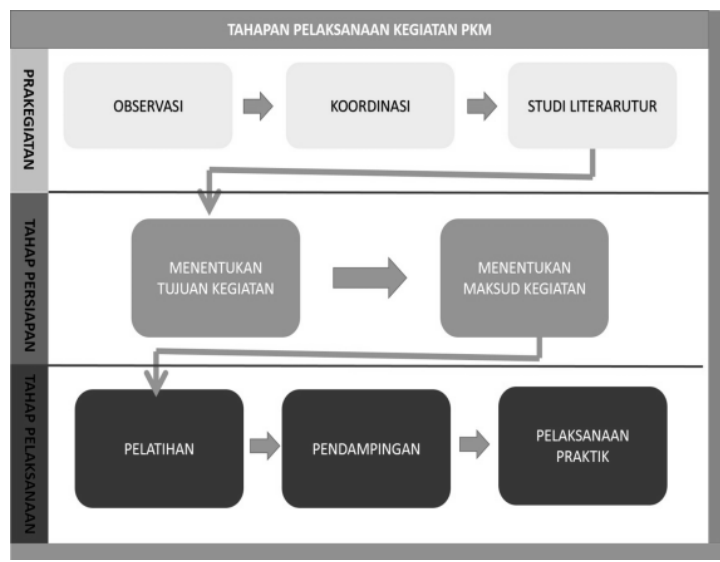

\section{Gambar 1. Metode Pelaksanaan Pengabdian}

Tahapan pelatihan ini dibagi menjadi 2 yaitu persiapan dan pelaksanaan. Tahap persiapan terdiri dari koordinasi dengan pihak sekolah sekolah, persiapan narasumber, persiapan panitia pelatihan berupa surat, administrasi, serta fasilitas. Tahap pelaksanaan terdiri dari tahap pemberian materi, diskusi terbatas, serta praktik penggunaan gawai serta evaluasi kemudian pendampingan.

Workshop ini meliputi pelatihan menggunakan aplikasi pembelajaran yang dapat dimanfaatkan guru di kelas. Aplikasi gratis yang dapat digunakan guru sebenarnya dapat digunakan untuk menstimulus siswa sehingga pembelajaran berlangsung interaktif. Setelah pemaparan materi selesai, dilakukannya praktik menggunakan aplikasi Kahoot dibimbing oleh tim pengabdian. Peserta kegiatan dilatih dalam bermain game pembelajaran. Berikut gambar kegiatan workshop pembelajaran berbasis mobile learning.

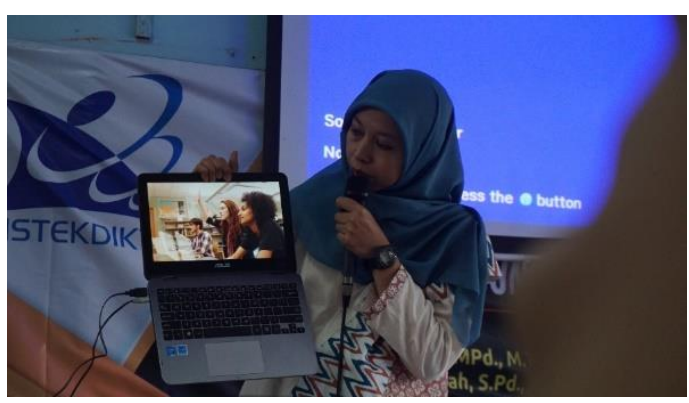

\section{Gambar 2. Workshop Pembelajaran berbasis mobile learning}

Pada kegiatan ini guru sangat antusias untuk mencoba game pembelajaran di dalam kegiatan praktiknya. Selain itu, karena waktu yang sangat terbatas, peserta kegiatan diberikan tugas mandiri di rumah membuat akun beberapa aplikasi pembelajaran.

Pendampingan dilakukan selama beberapa bulan sehingga guru terampil dalam menggunakan aplikasi tersebut di kelas.

\section{Hasil dan Pembahasan}

Pelatihan menggunakan aplikasi pembelajaran yang dapat dimanfaatkan guru di kelas. Aplikasi gratis yang dapat digunakan guru sebenarnya dapat digunakan untuk menstimulus siswa 
sehingga pembelajaran berlangsung interaktif.

\begin{tabular}{lll}
\multicolumn{2}{r}{ Setelah pemaparan } & materi \\
selesai, dilakukannya & praktik \\
menggunakan aplikasi & Kahoot
\end{tabular}
dibimbing oleh tim pengabdian. Peserta kegiatan dilatih dalam bermain game pembelajaran.

Pendampingan selanjutnya adalah implementasi penggunaan beberapa aplikasi yang berguna untuk guru dan siswa yang menunjang pembelajaran. Pendampingan ini dilakukan dengan cara simulasi yang dilakukan guru dengan bersama-sama. Simulasi yang dilakukan oleh 25 peserta, peserta ada yang sebagai siswa dan observer yang akan menilai pembelajaran.

Pendampingan ini juga guru berlatih untuk membuat konten di Kahoot dan Quizizz yang akan bisa digunakan oleh siswa. Guru secara berkelompok membuat soal di Quizizz dan Kahoot. Sebelumnya peserta membuat akun di masing masing aplikasi dan mempost konten di website aplikasi. Indikator keberhasilan masingmasing peserta adalah jika mampu membuat konten dan berhasil memposting. Setelah pendampingan berakhir, didapat 30 peserta mampu membuat konten di aplikasi dan memposting di website aplikasi Quizizz. Maka dapat dikatakan 100\% peserta mengalami peningkatan keterampilan dalam penggunaan aplikasi mobile learning.

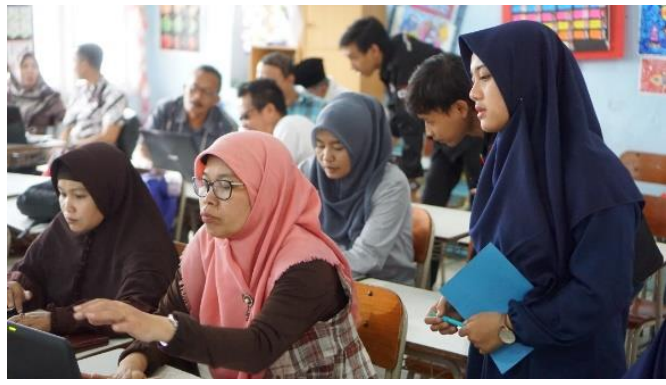

Gambar 3. Pendampingan Pembelajaran berbasis mobile learning

Kegiatan pendampingan berlangsung secara serius dan semangat sambil sesekali bertanya kepada tim jika mengalami kesulitan saat mempelajari konten. Di akhir pendampingan peserta diminta simulasi sebagai guru mencoba aplikasi dan mempraktekannya di kelas bersama guru yang lain.

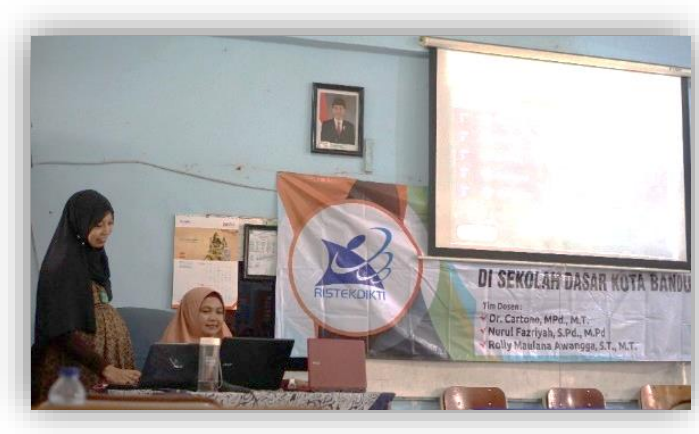

\section{Gambar 4. Guru mensimulasikan pembelajaran mobile learning}

Berdasarkan hasil pendampingan pembelajaran mobile learning, masing masing guru mempraktikkannya di kelas masingmasing dengan siswanya. Mereka melaporkan bahwa siswa SD sangat antusias dan bersemangat mencoba berbagai aplikasi mobile learning di kelasnya sebagai media pembelajaran. 


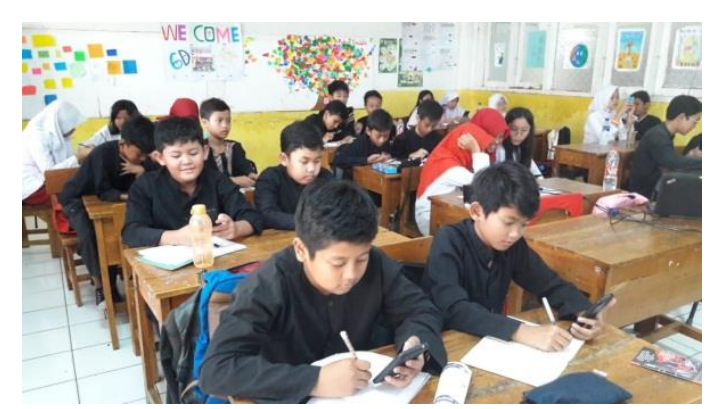

Gambar 5. Siswa menggunakan aplikasi Quizizz saat belajar di kelas

Hasil dari pendampingan dan workshop memperoleh capaian di akhir program yaitu sebagai berikut :

Tabel 1. Capaian Pengetahuan setelah Pelatihan saat dilakukan pretest dan post test

\begin{tabular}{|l|l|l|l|l||}
\hline No & Pelatihan & $\begin{array}{l}\text { Pret } \\
\text { est }\end{array}$ & $\begin{array}{l}\text { Poste } \\
\text { st }\end{array}$ & $\begin{array}{l}\text { Pening } \\
\text { katan }\end{array}$ \\
\hline 1 & $\begin{array}{l}\text { Perancangan } \\
\text { Pembelajaran } \\
\text { berbasis } \\
\text { mobile } \\
\text { learning di } \\
\text { sekolah dasar }\end{array}$ & $100 \%$ & $75 \%$ \\
& & & & \\
\hline
\end{tabular}

\section{Kesimpulan dan Saran}

Pelatihan Pembelajaran berbasis mobile learning bagi Guru SDN 164 Karangpawulang Kecamatan Lengkong Kota Bandung Provinsi Jawa Barat peningkatan pemahaman dan mereka mampu dalam membuat pembelajaran berbasis mobile learning. Selain itu, adanya motivasi yang tinggi dari peserta kegiatan untuk mengaplikasikannya dalam pembelajaran di kelas.

Praktik pembelajaran berbasis mobile learning yang dilakukan kelas tinggi dapat membuat siswa bergairah dalam belajar serta guru merasakan manfaatnya yaitu mmepermudah dalam mengevaluasi siswa dan menambah sumber belajar bagi siswa.

\section{DAFTAR PUSTAKA}

Kadi, T., \& Awwaliyah, R. (2017). Inovasi Pendidikan: Upaya Penyelesaian Problematika Pendidikan Di Indonesia. Jurnal Islam Nusantara, 1(2), 144-155. https://doi.org/10.33852/jurnalin.v1i 2.32

Maovangi Day, Vania; Qodariah, S. (2019). Menumbuhkan Literasi Digital pada Anak Usia Sekolah 612 Tahun. Prosiding Nasional Psikologi, 2, 1-9. https://doi.org/10.1017/CBO978110 7415324.004

National Education Association. (2014). Preparing 21st Century Students for a Global Society: An Educator' $s$ Guide to the "Four Cs ." Los Angeles: NEA. Retrieved from http://www.nea.org/assets/docs/AGuide-to-Four-Cs.pdf

Pusat Data Dan Teknologi Informasi Kementerian Pendidikan dan Kebudayaan. (2020). Jumlah Data Satuan Pendidikan (Sekolah) Per Kabupaten/Kota: Kota Bandung. Retrieved from https://referensi.data.kemdikbud.go.i d/index11_sd.php?kode=026000\&le vel $=2$

Wahyuni, S. E., Widiyatun, F., Widyasari, H., \& Suharmanto, P. (2019). Peningkatan Semangat Belajar dengan Peta Konsep dan Media Pembelajaran menggunakan Program Mindmapple. ETHOS (Jurnal Penelitian Dan Pengabdian), 7(2), 178-181. https://doi.org/10.29313/ethos.v7i2. 4415

Wati, T., \& Set, H. B. (2018). Pelatihan Manajemen Konten Berbasis ELearning Bagi Guru - Guru Pondok Pesantren Kelurahan Sasak Panjang, Kabupaten Bogor. ETHOS (Jurnal 
204 | Nurul Fazriyah, et al.

Penelitian Dan Pengabdian), 6(2), 226-232. Retrieved from https://ejournal.unisba.ac.id/index.p hp/ethos/article/view/3236/pdf 